\title{
Intensi Berwirausaha Ditinjau Dari Adversity Quotient Pada Mahasiswa Program Studi Manajemen Universitas Katolik Soegijapranata Semarang
}

\author{
Ika Julita dan Sumbodo Prabowo \\ Fakultas Psikologi Unika Soegijapranata, Semarang
}

\begin{abstract}
This study aims to determine the relationship between adversity quotient with the intention of entrepreneurship in the students of Management Studies Program Catholic University Soegijapranata Semarang. Hypothesis of this research is there is positive relation between adversity quotient with entrepreneurship intention to student of Management Study Program of Catholic University Soegijapranata Semarang. The population of this research are students of Management Studies Program of Catholic University Soegijapranata Semarang force 2013 and 2014 which take the entrepreneurship concentration. The sampling technique used purposive sampling and accidental technique. Subjects who got as many as 38 students, with students of force 2013 say 16 people and force 2014 with 22 people. The data analysis is a measure of scale, with Pearson's exclusive Product Moment technique. The result of data analysis shows that adversity quotient is highly positive correlation to entrepreneurship intention, which reported with rxy value $=0,561$ with $p$ value $<0,01$. The effective contribution of adversity quotient to the intentions of entrepreneurship is $31.47 \%$. Thus the conclusion of this study is the accepted hypothesis.
\end{abstract}

Keywords: adversity quotient, intention of entrepreneurship

\section{PENDAHULUAN}

Saat ini gelar ijazah pendidikan tinggi tidak menjamin seseorang akan dengan mudah untuk mendapatkan pekerjaan yang sesuai dengan minat dan keahlian serta memberi imbalan yang memadai. Kesulitan lulusan perguruan tinggi memperoleh pekerjaan bisa terlihat dari angka pengangguran lulusan perguruan tinggi Indonesia yang terbilang cukup besar dan bahkan meningkat di tahun ini (Gewati, 2016).

Berdasarkan data Badan Pusat Statistik (2017) pada Februari 2017, di Indonesia ada $12,23 \%$ (856.644 orang) dari total penganggur yang merupakan lulusan perguruan tinggi. Angka tersebut meningkat dibandingkan angka pengangguran lulusan perguruan tinggi pada Agustus 2016 yang hanya 11,19\% (786.971 orang).

Besarnya jumlah pengangguran lulusan perguruan tinggi memang tidak bisa ditampik. Hal ini salah satunya disebabkan karena jumlah tenaga kerja yang ada di Indonesia berbanding terbalik dengan ketersediaan lapangan kerja. Kondisi ini diharapkan dapat membuka pandangan di kalangan lulusan perguruan tinggi untuk mencari alternatif pekerjaan yang lain. Alternatif yang dimaksudkan adalah berusaha menciptakan lapangan pekerjaan sendiri 
atau lebih dikenal dengan berwirausaha. Wijaya (2007, h.117) mengungkapkan berwirausaha merupakan salah satu pilihan yang rasional mengingat sifatnya yang mandiri, sehingga tidak tergantung pada ketersediaan lapangan kerja yang ada.

Wirausaha merupakan kemampuan melihat dan menilai peluang bisnis serta kemampuan mengoptimalkan sumber daya dan mengambil tindakan serta risiko dalam rangka menyukseskan bisnis (Kurniasih, Lestari \& Herminingsih, 2013, h.130). Alma (2011, h.1) mengungkapkan semakin maju suatu negara semakin banyak orang terdidik dan banyak pula orang menganggur maka semakin dirasakan pentingnya dunia wirausaha. Dengan kata lain pembangunan akan lebih berhasil jika ditunjang oleh wirausahawan yang dapat membuka lapangan kerja.

Zimmerer (dalam Suharti \& Sirine, 2011, h.125) menyatakan bahwa salah satu faktor pendorong pertumbuhan kewirausahaan di suatu negara terletak pada peranan perguruan tinggi melalui penyelenggaraan pendidikan kewirausahaan. Pihak perguruan tinggi bertanggungjawab dalam mendidik dan memberikan kemampuan wirausaha kepada para mahasiswanya dan memberikan motivasi untuk berani memilih berwirausaha sebagai karirnya.

Program Studi Manajemen Universitas Katolik Soegijapranata Semarang melalui salah satu konsentrasi yang dimiliki, yaitu konsentrasi kewirausahaan berupaya mendorong mahasiswanya untuk menjadi wirausahawan setelah lulus nanti. Mahasiswa yang mengambil konsentrasi kewirausahaan akan mendapatkan pendidikan kewirausahaan baik melalui teori maupun praktek, dengan harapan ketika berada di tingkat akhir mahasiswa sudah memiliki kemampuan dan sudah siap untuk terjun ke dunia wirausaha nantinya.

Salah satu prediktor untuk mengetahui siap atau tidaknya mahasiswa tingkat akhir untuk menjadi wirausaha di masa yang akan datang adalah dengan mengukur intensi berwirausahanya (Krueger, Reilly \& Carsrud, 2000, h.412). Choo \& Wong (dalam Indarti \& Rostiani, 2008, h.4) mengungkapkan intensi berwirausaha dapat dijadikan sebagai pendekatan yang masuk akal untuk memahami siapasiapa yang akan menjadi wirausahawan.

Hasil wawancara peneliti menunjukkan bahwa ada perbedaan intensi berwirausaha pada 30 orang mahasiswa Program Studi Manajemen Universitas Katolik Soegijapranata Semarang yang notabene sama-sama mendapatkan bekal dan pendidikan kewirausahaan di kampus. Duabelas orang mahasiswa memiliki intensi yang kuat untuk berwirausaha, sedangkan 22 orang mahasiswa mengaku memiliki intensi berwirausaha yang lemah.

Intensi berwirausaha pada mahasiswa lemah karena kurangnya percaya diri, ragu-ragu dan takut gagal sehingga mahasiswa tersebut tidak siap menghadapi rintangan/kesulitan yang ada. Dengan demikian hanya seseorang yang mampu bertahan dan mengatasi rintangan/kesulitan sajalah yang memiliki intensi berwirausaha yang kuat. Kemampuan untuk bertahan dan mengatasi rintangan/kesulitan tersebut oleh Stoltz (2004) disebut dengan adversity quotient.

Penelitian ini kemudian dilakukan dengan tujuan untuk menguji secara empiris hubungan antara adversity quotient dengan intensi berwirausaha pada mahasiswa Program Studi Manajemen Universitas Katolik Soegijapranta Semarang.

Menumbuhkembangkan jiwa kewirausahaan dapat diawali dengan menumbuhkan keinginan dan kesungguhan untuk berwirausaha pada 
diri. Apabila keinginan atau niat berwirausaha telah tertanam kuat dalam diri maka kemungkinan untuk merealisasikan niat tersebut dalam bentuk suatu usaha juga akan kuat terlaksana (Arisandi, 2016, h.5).

Keinginan atau niatan untuk mendirikan sebuah usaha di masa depan disebut juga dengan intensi berwirausaha (Van Gelderen, dkk., 2008, h.540). Intensi berwirausaha memiliki empat aspek, yang terdiri dari: desires, preferences, plans dan behavior expectancies (Van Gelderen, dkk., 2008, h.543).

Wijaya (2007, h.120-121) mengungkapkan intensi berwirausaha dipengaruhi oleh faktor internal dan faktor eksternal. Faktor internal adalah faktor yang berasal dari dalam diri individu, yang terdiri dari faktor psikologis dan faktor sosiodemografi. Sedangkan faktor eksternal adalah faktor yang berasal dari luar individu, yang terdiri dari lingkungan keluarga dan pendidikan.

Dalam literatur kewirausahaan, faktor terpenting yang membentuk intensi berwirausaha adalah faktor psikologis. Faktor-faktor psikologis menjelaskan pola bertindak melalui intensi seseorang dalam memilih berwirausaha sebagai karir (Sagiri \& Appolloni, 2009, h.72).

Berdasarkan sejumlah penelitian (Wijaya, 2007; Zahreni \& Pane, 2012; Handaru, Parimita \& Mufdhalifah, 2015; Fradani, 2016; Firmansyah, Djatmika \& Hermawan, 2016) faktor psikologis yang berpengaruh terhadap intensi berwirausaha yaitu adversity quotient. Adversity quotient merupakan suatu kemampuan yang dimiliki seseorang untuk dapat bertahan dalam menghadapi segala macam peristiwa yang menimbulkan kesulitan (Stoltz, 2004).

Saat ingin mulai membuka suatu usaha, individu akan menemukan beberapa kesulitan/hambatan. Individu yang memiliki adversity quotient yang rendah akan mengalami tekanan saat menghadapi hambatan tersebut sehingga dirinya menjadi putus asa. Hambatanhambatan tersebut pada akhirnya melemahkan intensi berwirausahanya. Berbeda halnya dengan individu yang memiliki adversity quotient yang tinggi, hambatan-hambatan yang ada tidak akan melemahkan intensi berwirausaha. Pada kenyataannya, dengan menghadapi hambatan-hambatan tersebut justru akan menjadi pemicu untuk menguatkan intensi berwirausaha (Firmansyah, dkk. 2016. h.46).

Individu dengan adversity quotient tinggi akan mempunyai kemampuan untuk menangkap peluang usaha (wirausaha) karena memiliki kemampuan untuk menanggung resiko, orientasi pada peluang/inisiatif, kreativitas, kemandirian dan pengerahan sumber daya, sehingga adversity quotient dalam diri individu memiliki pengaruh terhadap keinginan untuk berwirausaha (Zahreni \& Pane, 2012, h.174). Dengan memiliki adversity quotient yang tinggi individu dapat menjadi lebih kreatif, bertangung jawab, mandiri dan bekerja keras, hal-hal inilah sebagian karakteristik untuk menjadi seorang wirausahawan. Individu dengan adversity quotient rendah cenderung tidak memiliki sifat-sifat tersebut sehingga dapat melemahkan keinginannya untuk berwirausaha (Fradani, 2016, h.55).

Berwirausaha adalah karir yang memberikan otonomi penuh, tetapi di lain pihak, berwirausaha juga menawarkan tantangan dan resiko yang harus dihadapi. Setiap individu memiliki ketakutan akan kegagalan, tetapi individu yang ingin sukses tidak akan berhenti saat mengalami kegagalan. Oleh karena itu, individu yang memiliki adversity quotient yang tinggi akan cenderung terus mencoba untuk mencapai tujuan dan bisa sukses dalam karir wirausahanya. Sebagai tambahan, seorang wirausahawan adalah seseorang 
yang memiliki kemampuan untuk mengidentifikasi peluang di tengah kesulitan (Firmansyah, dkk. 2016. h.51). Hipotesis peneltian ini adalah Ada hubungan positif antara adversity quotient dengan intensi berwirausaha pada mahasiswa Program Studi Manajemen Universitas Katolik Soegijapranata Semarang”. Semakin tinggi adversity quotient maka semakin kuat intensi berwirausaha. Sebaliknya semakin rendah adversity quotient maka semakin lemah intensi berwirausaha.

\section{METODE}

Subjek dalam penelitian ini adalah mahasiswa Program Studi Manajemen Universitas Katolik Soegijapranata Semarang yang memiliki ciri-ciri: (1) Mahasiswa angkatan 2013 dan 2014. Dengan pertimbangan, mahasiswa angkatan tersebut tercatat sebagai mahasiswa yang berada di tingkat akhir; (2) Mengambil konsentrasi kewirausahaan; (3) Belum pernah memiliki pengalaman berwirausaha atau tidak sedang memiliki usaha secara mandiri; (4) Orang tua dari mahasiswa tidak memiliki usaha secara mandiri.

Teknik pengambilan sampel yang digunakan untuk penelitian ini adalah dengan menggunakan teknik aksidental.

Metode pengumpulan data dalam penelitian ini menggunakan metode skala. Ada dua skala yang akan digunakan dalam penelitian ini, yaitu skala intensi berwirausaha dan skala adversity quotient. Analisis data dengan menggunakan Korelasi Product Moment Pearson.

\section{HASIL PENELITIAN}

1. Uji Normalitas

a. Intensi Berwirausaha

Uji normalitas pada skala intensi berwirausaha menggunakan uji KolmogorovSmirnov dengan nilai K-S-Z sebesar 0,888 dengan nilai $p$ sebesar $0,409 \quad(p>0,05)$ yang berarti bahwa distribusi penyebaran item normal.

b. Adversity Quotient

Uji normalitas pada skala adversity quotient menggunakan uji KolmogorovSmirnov dengan nilai K-S-Z sebesar 0,752 dengan nilai $\mathrm{p}$ sebesar 0,624 (p>0,05) yang berarti bahwa distribusi penyebaran item normal.

2. Uji Linearitas

Hasil uji linearitas menunjukkan adanya hubungan yang linier antara variabel X (Adversity Quotient) dan variabel Y (Intensi Berwirausaha) dengan Flinear $=16,516$ dan nilai $\mathrm{p}$ $=0,000(p<0,05)$.

3. Uji Hipotesis

Hasil dari analisa data dengan teknik korelasi Product Moment dari Pearson menunjukkan adanya hubungan positif yang sangat signifikan antara adversity quotient dengan intensi berwirausaha. Hal ini dibuktikan dengan $\mathrm{r}_{\mathrm{xy}}=0,561$ dengan nilai $\mathrm{p}=0,000(\mathrm{p}<0,01)$.

4. Analisa Tambahan

Peneliti melakukan analisa tambahan untuk mengetahui gambaran intensi berwirausaha yang dimiliki oleh subjek. Aspek demografis yang dijadikan perbandingan oleh peneliti adalah jenis kelamin. Melalui perhitungan statistik tambahan diketahui tidak ada perbedaan intensi berwirausaha pada laki-laki dan perempuan. Hal ini diketahui dari nilai $\mathrm{t}$ hitung $=$ $0,262(p>0,05)$.

\section{DISKUSI}

Berdasarkan uji hipotesis dengan menggunakan teknik Korelasi Product Moment dari Pearson diperoleh bahwa hipotesis yang diajukan oleh peneliti diterima yaitu "Ada hubungan positif antara adversity quotient dengan intensi berwirausaha" di mana berdasarkan hasil hitungan, hubungan 
antara variabel Adversity Quotient dan variabel Intensi Berwirausaha ialah hubungan positif yang sangat signifikan. Hal ini dibuktikan dengan nilai $\mathrm{r}_{\mathrm{xy}}=$ 0,561, $\mathrm{p}<0,01$ artinya bahwa Semakin tinggi adversity quotient maka semakin kuat intensi berwirausaha. Sebaliknya semakin rendah adversity quotient maka semakin lemah intensi berwirausaha.

Berdasarkan hasil penelitian didapatkan bahwa sumbangan efektif adversity quotient terhadap intensi berwirausaha ialah 31,47 \% sedangkan sisanya yaitu 68,53 \% dipengaruhi oleh faktor lain yang tidak diteliti seperti sifat-sifat personal, lingkungan keluarga, lingkungan sosial ekonomi, dukungan lingkungan dan dukungan sosial.

Hasil penelitian ini mendukung penelitian Wijaya (2007) di SMKN 7 Yogyakarta yang menemukan bahwa adversity quotient dalam diri seseorang memiliki hubungan dengan intensi berwirausaha, yang mana seseorang dengan adversity quotient tinggi akan memiliki kemampuan untuk menangkap peluang usaha karena memiliki kemampuan menanggung resiko, orientasi pada peluang/ inisiatif, kreativitas, kemandirian dan pengerahan sumber daya. Dengan demikian, seseorang yang memiliki adversity quotient tinggi akan lebih mudah menjalani profesi sebagai seorang wirausahawan.

Hasil penelitian ini juga mendukung temuan penelitian Fradani (2016) di SMKN Bojonegoro. Fradani (2016) mengemukakan bahwa dengan memiliki adversity quotient, siswa dapat menjadi lebih kreatif, bertanggungjawab, mandiri dan bekerja keras. Hal-hal inilah yang menjadi sebagian karakteristik untuk menjadi seorang pengusaha. Apabila seseorang memiliki adversity quotient yang rendah mereka cenderung tidak memiliki sifatsifat tersebut sehingga dapat melemahkan niat seseorang untuk berwirausaha.
Adversity quotient merupakan suatu hal yang penting, terutama saat seseorang memiliki niatan (intensi) untuk membuka sebuah usaha mandiri. Adversity quotient memberitahu sejauh mana seseorang dapat mengatasi kesulitan yang dihadapi saat membuka sebuah usaha. Apakah dengan adanya kesulitan menjadikan seseorang termotivasi untuk memperbaiki diri atau malah menjadikan alasan seseorang untuk mundur (Firmansyah, dkk., 2016, h.52). Hasil penelitian terhadap variabel adversity quotient diperoleh mean empirik sebesar 35,00 dengan standar deviasi sebesar 4,466 sedangkan mean hipotetiknya sebesar 30. Nilai mean empirik masuk dalam kategori sedang cenderung tinggi sehingga dapat disimpulkan bahwa subjek memiliki adversity quotient yang sedang cenderung tinggi.

Peneliti sempat melakukan wawancara dengan beberapa subjek penelitian. Berdasarkan wawancara, diketahui adversity quotient subjek terbentuk karena selama perkuliahan subjek pernah mengikuti kegiatan praktek yang berhubungan dengan wirausaha seperti Kuliah Kerja Usaha, sehingga subjek bisa belajar secara langsung tentang kegiatan usaha dan belajar mengidentifikasi peluang yang ada di sekitarnya.

Intensi berwirausaha menjadi prediktor terbaik bagi perilaku entrepreneurial seseorang dan oleh karenanya dapat dijadikan sebagai pendekatan dalam mengkategorikan entrepreneur dengan non-entrepreneur (Indarti \& Rostiani, 2008, h.4). Hasil penelitian terhadap variabel intensi berwirausaha diperoleh mean empirik sebesar 39,50 dengan standar deviasi sebesar 5,622 sedangkan mean hipotetiknya sebesar 35. Nilai mean empirik masuk dalam kategori sedang cenderung tinggi sehingga dapat disimpulkan bahwa subjek memiliki intensi berwirausaha yang sedang 
cenderung tinggi. Ada 4 aspek yang digunakan dalam mengukur intensi berwirausaha yaitu desires, preferences, plans dan behavior expectancies. Aspek desires memiliki mean empirik sebesar 12,32 dan tergolong tinggi, aspek preferences memiliki mean empirik sebesar 8,74 dan tergolong sedang cenderung tinggi, aspek plans memiliki mean empirik sebesar 7,89 dan tergolong sedang cenderung tinggi, aspek behavior expectancie memiliki mean empirik sebesar 10,55 dan tergolong sedang cenderung tinggi. Jika ke-4 aspek tersebut dibandingkan dengan jumlah item valid, maka desires mendapati skor 3,08 lalu preferences mendapat skor 2,91 kemudian plans mendapat skor 2,63 dan behavior expectancies mendapat skor 2,6375. Dari data tersebut terlihat bahwa aspek plans menjadi aspek dengan skor terendah. Banyak subjek yang belum memiliki rencana tentang usahanya kelak.

Dari hasil penelitian, diketahui intensi berwirausaha pada mahasiswa Program Studi Manajemen yang mengambil konsentrasi kewirausahaan adalah sedang cenderung tinggi. Selain itu, banyak mahasiswa yang belum memiliki rencana tentang usahanya kelak. Padahal seperti yang tertera di buku Program Studi Manajemen, konsentrasi kewirausahaan diselenggarakan untuk menghasilkan lulusan yang mampu dan siap menjadi wirausaha sehingga diharapkan mahasiswa terutama mahasiswa tingkat akhir memiliki intensi berwirausaha yang tinggi. Namun kenyataannya setelah dilakukan penelitian terhadap subjek yang merupakan mahasiswa tingkat akhir, didapati bahwa tingkat intensi berwirausahanya masih sedang cenderung tinggi. Hal ini sesuai dengan permasalahan yang diajukan pada pra penelitian, dimana intensi berwirausaha pada mahasiswa Program Studi Manajemen yang mengambil konsentrasi kewirausahaan cenderung kurang kuat.

Berdasarkan hasil temuan diketahui tidak ada perbedaan intensi berwirausaha pada laki-laki dan perempuan. Hal ini mendukung penelitian dari Chairy (2011) yang menyatakan bahwa tidak ada perbedaan intensi berwirausaha antara laki-laki maupun wanita.

Di Indonesia cukup banyak wanita yang bergerak dalam bidang bisnis, yang lebih dikenal dengan istilah Wanita Pengusaha Indonesia. Bahkan mereka mendirikan sebuah asosiasi, yang dinamakan Ikatan Wanita Pengusaha Indonesia (IWAPI). Menurut data BPS (dalam Rahayu, 2017) jumlah Wanita Pengusaha Indonesia cukup besar dan mengalami peningkatan di tahun ini, yaitu sekitar 14,3 juta orang. Naluri kewanitaan yang bekerja lebih cermat dan majunya dunia pendidikan merupakan faktor yang menunjang mengapa wanita banyak yang terjun ke dunia wirausaha. Selain itu, cukup banyak ragam jenis wirausaha yang bisa digeluti oleh wanita seperti bisnis jasa, pendidikan, konsultan dan public relations, membuat wanita memiliki intensi berwirausaha yang tidak berbeda dengan dengan laki-laki (Alma, 2011, h.44-47).

\section{SIMPULAN}

Berdasarkan hasil penelitian yang dilakukan maka dapat disimpulkan bahwa : Hipotesis dapat diterima yaitu Ada hubungan positif yang sangat signifikan antara adversity quotient dengan intensi berwirausaha pada mahasiswa Program Studi Manajemen Universitas Katolik Soegijapranata Semarang. Semakin tinggi adversity quotient maka semakin kuat intensi berwirausaha. Sebaliknya semakin rendah adversity quotient maka semakin lemah intensi berwirausaha. Adversity quotient berpengaruh pada Intensi Berwirausaha sebesar 31,47 \%. 
Berdasarkan penelitian yang telah dilakukan, maka peneliti dapat memberikan beberapa saran yaitu :

1. Bagi Subjek Penelitian

Mahasiswa disarankan untuk menambah pengalaman praktek yang berhubungan dengan wirausaha, salah satunya yaitu dengan magang di secara intensif di tempat-tempat usaha. Mahasiswa hendaknya benar-benar terlibat secara aktif selama magang, sehingga mahasiswa bisa memahami dengan baik situasi usaha/industri yang sesungguhnya.

2. Bagi Program Studi Manajemen Program Studi Manajemen disarankan untuk memberi program atau mata kuliah dalam rangka untuk meningkatkan adversity quotient para mahasiswa. Dalam pemberian program atau mata kuliah tersebut disesuaikan untuk meningkatkan aspek dari adversity quotient, yang terdiri dari Control, Origin-Ownership, Responsibilty dan Endurance.

3. Bagi Peneliti Selanjutnya

Penelitian sejenis di masa datang disarankan untuk menambahkan variabel-variabel lain yang mungkin memiliki hubungan dengan intensi berwirausaha sehingga akan lebih terlihat faktor lain yang memberi sumbangan efektif terbesar.

\section{DAFTAR PUSTAKA}

Alma, B. (2011). Kewirausahaan. Bandung: Alfabeta.

Arisandi, D. (2016). Intensi Berwirausaha Mahasiswa

Pascasarjana Institut Pertanian Bogor Pada Bidang Agribisnis (Laporan Penelitian). Sekolah Pascasarjana Institut Pertanian Bogor, Bogor.

Badan Pusat Statistik. (2017). Penduduk Berumur 15 Tahun Ke Atas
Menurut Pendidikan Tertinggi yang Ditamatkan dan Jenis Kegiatan Selama Seminggu yang Lalu, 2008-2017. Diunduh dari https://www.bps.go.id.

Chairy. (2011). Pengaruh Karakteristik Entrepreneurial, Jenis Etnis, Jenis Kelamin dan Profesi Orang Tua Terhadap Intensi Berwirausaha Mahasiswa. Prosiding dalam Rangkaian Seminar Internasional dan Call for Papers "Towards Excelent Small Business", Yogyakarta.

Firmansyah, A.H., Djatmika, E.T. \& Hermawan, A. (2016). The effect of adversity quotient and entrepreneurial self-efficacy on entrepreneurial intention through entrepreneurial attitude. Journal of Business and Management, 18 (5), 45-5. DOI: $10.9790 / 487 X-$ 1805014555.

Fradani, A.C. (2016). Pengaruh dukungan keluarga, kecerdasan adversitas dan efikasi diri pada intensi berwirausaha siswa SMK negeri 2 bojonegoro. Jurnal Edutama, 3 (1), 47-62.

Gewati, M. (2016, 23 April). Kenapa Lulusan Perguruan Tinggi Makin Susah Mendapatkan Pekerjaan?. Diunduh dari http://www.kompas.com.

Handaru, A.W., Parimita, W. \& Mufdhalifah I.W. (2015). Membangun intensi berwirausaha melalui adversity quotient, self efficay, dan need for achievement. Jurnal Manajemen dan Kewirausahaan. , 17 (2), 145-166. DOI: 10.9744/jmk.17.2.155-166.

Indarti, N. \& Rostiani, R. (2008). Intensi kewirausahaan mahasiswa: studi perbandingan antara indonesia, jepang dan norwegia. Jurnal Ekonomika dan Bisnis Indonesia, 23 (4), 2-27.

Krueger, N.F., Reilly, M.D. \& Carsrud, A.L. (2000). Competing models 
of entrepreneurial intentions. Journal of Business Venturing, 15, 411-432.

Kurniasih, A., Lestari S.D. \& Herminingsih A. (2013). Persepsi mahasiswa terhadap kuliah kewirausahaan dan pengaruhnya terhadap sikap dan intensi berwirausaha mahasiswa. Jurnal Ilmu Ekonomi dan Sosial, 2 (2), 129-146.

Rahayu, Y.A. (2017, 15 Mei). Jumlah Pengusaha Wanita Meningkat Jadi 14,3 Juta Orang. Diunduh dari http://merdeka.com.

Sagiri, S. \& Appolloni, A. (2009). Identifying the effect of psychological variables on entrepreneurial intentions. DSM Business Review, 2 (2), 61-86.

Stoltz, P.G. (2004). Adversity Quotient: (Mengubah Hambatan Menjadi Peluang) (Alih Bahasa: T. Hermaya). Jakarta: PT. Grasindo.

Suharti, L. \& Sirine, H. (2011). Faktorfaktor yang berpengaruh terhadap niat kewirausahaan (entrepreneurial intention). Jurnal Manajemen dan Kewirausahaan, 13 (2), 124-134.

Van Gelderen, M., Brand, M., Van Praag, M., Bodewes, W., Poutsma, E. \& Van Gils, A. (2008) . Explaining entrepreneurial intentions by means of the theory of planned behaviour. Journal: Career Development International, 13 (6), 538-559. DOI: 10.1108/13620430810901688.

Wijaya, T. (2007). Hubungan adversity intelligence dengan intensi berwirausaha. Jurnal Manajemen dan Kewirausahaan, 9 (2), 117127.

Zahreni, S. \& Pane R.S.D. (2012). Pengaruh adversity quotient terhadap intensi berwirausaha. Jurnal Ekonom, 15 (4), 173-178. 